\title{
Effects on Heavy Metals in Karst Region Soil and the Enrichment Characteristics of Rice-Rape Rotation
}

\author{
Zhenming Zhang', Qinghai Zhang'*, Chenlong $\mathbf{T u}^{2}$, Jiachun Zhang ${ }^{3}$, \\ Changhu Lin², Hui Fang ${ }^{1,}$ Ximei Wen ${ }^{1}$ \\ ${ }^{1}$ Institute of Biology, Guizhou Academy of Sciences, Guiyang, Guizhou, P. R. China \\ ${ }^{2}$ Guizhou Medical University, Guiyang, Guizhou, P. R. China \\ ${ }^{3}$ Guizhou Botanical Garden, Guiyang, Guizhou, P. R. China
}

Received: 27 August 2018

Accepted: 27 October 2018

\begin{abstract}
Karst regions are relatively short of arable land, but heavy metals are at high levels in arable land. Under this circumstance, different tillage methods have different effects on the activity of heavy metals in soil. In this study, through field experiments and lab analysis, the effects of different rotation systems on the activity of heavy metals and the transport and enrichment of heavy metals in soil when rape and rice were in different growth stages were analyzed. The results show that in rice-rape rotation, the distribution of the heavy metal content in soil was different. The contents of $\mathrm{Cr}, \mathrm{Pb}$ and $\mathrm{Cu}$ in soil were at the level of "clean" and the content of $\mathrm{Cd}$ was at the level of middle pollution. The sequence of the enrichment factors in the growth of the rape was: $\mathrm{Cd}>\mathrm{Cu}>\mathrm{Pb}>\mathrm{Cr}$ and its ability to accumulate the same heavy metal varied from different growth stages; leaf, root and stem were main enrichment organs, among which stem had the weakest enrichment ability for $\mathrm{Cu}$, root was the main enrichment organ for $\mathrm{Pb}$ and rape had relatively weaker enrichment and transport ability for Cr. Rice mainly accumulated $\mathrm{Cd}$ and $\mathrm{Cu}$; it had relatively weaker enrichment ability for heavy meals in the seedling and tillering stages; its enrichment ability for $\mathrm{Cd}$ was gradually strengthened; and heavy metals were mainly enriched in rice's root system in various growth stages.
\end{abstract}

Keywords: soil heavy metal, transport and transformation, activity, rice-rape

\section{Introduction}

Cultivated land is the most precious non-renewable resource, the foundation of grain production and the material basis of the survival and development of

*e-mail: zhang6653578@163.com human beings [1]. China's cultivated land per capita is lower than world average due to the limited area and the insufficient reserve resources [2]. Since China implemented strict arable land polity in the 1990s, targeted protective measures have been gradually performed, but there are no obvious effects. According to the statistics from the Ministry of Land and Resources, China's cultivated area is currently only 
135 million $\mathrm{hm}^{2}$, quite close to the arable land minimum of 120 million $\mathrm{hm}^{2}$ [3-4]. The cultivated land resources are quite scare in Karst areas and its amount is declining gradually because of the changes of the soil heavy metal activity brought by the strong interference of agricultural activities [5]. Guizhou Province has a wide distribution of carbonate and the content of soil heavy metals is obviously higher than other areas in China [6]. The state of "high heavy metal background, low activity" led to a relatively lower biomass enrichment of soil heavy metals under natural conditions [7]. However, as the development of agricultural activities, the physicochemistry environment of the soil was changed and heavy metals were gradually activated [8]. Therefore, Guizhou has become a high-risk area of heavy metal exposure [9].

Rape is one of the most important oil crops in China and rice-rape rotation is one of the most significant rotation systems in southern China [10-11]. Currently, there are many reports about the fertilizer responses of nitrogen, phosphorous and kalium in rice-rape rotation, while there is little research on the heavy metals in rice-rape rotation [12]. However, on the one hand, as plants grow up, heavy metals are accumulated and transported within them [13]. On the other hand, the activity of heavy metals in soils is being changed under the interference of various agricultural activities. Ricerape rotation is a relatively normal phenomenon in the process of agricultural production in Guizhou [14]. Therefore, studying the enrichment of heavy metals and the transport regulations in different organs in various growth stages of the crops in rice-rape rotation can help to understand the dynamic distribution of heavy metals in crops, provide evidence for the activity regulation and pollution control of soil heavy metals in rice-rape rotation in Guizhou Province and contribute to the reduction of the heavy metal pollution in agricultural products.

\section{Materials and Methods}

\section{Experiment Material}

The study area $\left(27^{\circ} 30^{\prime} 11^{\prime \prime} \mathrm{N}, 106^{\circ} 44^{\prime} 28^{\prime \prime} \mathrm{E}\right)$ is located in Shiban, Bozhou District, Zunyi City, Guizhou Province, at an altitude of about $800 \mathrm{~m}$. The mean annual temperature (MAT) and mean annual precipitation (MAP) are $14.9^{\circ} \mathrm{C}$ and $1020.6 \mathrm{~mm}$. The climate is subtropical humid monsoon. The frost-free period lasts 291 days. It yields two crops a year, and the soil type is calcareous paddy soil. There is no sewage irrigation in this area, and there are no such pollution sources as mines nearby. The area is about $450 \mathrm{~m}^{2}(30 \times 15 \mathrm{~m})$.

The selected variety of oil seed rape is Youyan No. 57, which is a semi-winterness two-line hybrid type of Brassica featuring recessive genic male sterility, with a national approval of No. 2013001. The seedlings of this cultivar are semi-erect, with an average height of about $193 \mathrm{~cm}$, and an average crop yield of about $296.4 \mathrm{~kg} \cdot \mathrm{mu}^{-1}\left(1 \mathrm{mu} \approx 666.67 \mathrm{~m}^{2}\right)$. It is lodging-resistant and suitable for cultivation in Sichuan, Yunnan, Guizhou, Chongqing and other winter yield areas. The rice variety is Yixiang 725. The variety was cultivated by the Research Institute of Agricultural Sciences of Mianyang through combining Yixiang 1A with the restorative Mianhui 725 . The average plant height is $117 \mathrm{~cm}$, the panicle length is about $26.39 \mathrm{~cm}$, and the yield is about $564 \mathrm{~kg} \cdot \mathrm{mu}^{-1}$. It is suitable for cultivation in plain and hilly areas in Sichuan Province, the whole of Hunan Province, Zunyi City of Guizhou Province, and areas in Chongqing Province below $1000 \mathrm{~m}$ altitude.

\section{Data Source}

The rice-rape rotation is designed according to the local traditional farming methods, with the rape soaked with water after harvesting for transplanting. The rape is sown in late October and harvested at the end of May in the following year. Decomposed organic manure is used as base fertilizer before planting, with the application rate of $2000 \mathrm{~kg} \cdot \mathrm{mu}^{-1}$. The urea (with total nitrogen rate $\geq 46.4 \%$ ) is used as top dressing after sampling at the seedling stage, with the application rate of $10 \mathrm{~kg} \cdot \mathrm{mu}^{-1}$. The space between rows of seedlings is about $35 \mathrm{~cm}$, and that between seedlings is $20 \mathrm{~cm}$. The rice is raised in early May of the following year, transplanted in early June, harvested in mid-September, and weeded with Benzyl herbicide one week after transplanting. The dosage is 25.5 to $35.8 \mathrm{~kg} \cdot \mathrm{mu}^{-1}$.

The top layer soil $(0-20 \mathrm{~cm})$ covering the root is collected before sowing and at four growth stages (the seedling stage, bolting/tillering stage, filling stage and harvesting stage) of rape and rice respectively. 5 sampling points are set for each sampling unit. When collecting samples, the sampling points of the plants correspond to the soil sampling points respectively. In each soil sampling unit, the sampling of the plant is collected where the soil sample is drawn and in the same amount. But at least one sample is brought back to the lab and its organs are treated separately. The sample is washed with tap water, then rinsed with de-ionized water, removed of water, dried, ground, and sealed in a polyethylene plastic bag.

Table 1. Soil environmental quality indicators (GB15618-1995).

\begin{tabular}{|c|c|c|c|}
\hline \multirow{2}{*}{ Element } & \multicolumn{3}{|c|}{ Limit of content $(\mathrm{mg} / \mathrm{kg})$} \\
\cline { 2 - 4 } & $\mathrm{pH}<6.5$ & $6.5<\mathrm{pH}<7.5$ & $\mathrm{pH}>7.5$ \\
\hline $\mathrm{Cr}$ & 150 & 200 & 250 \\
\hline $\mathrm{Cd}$ & 0.3 & 0.3 & 0.6 \\
\hline $\mathrm{Pb}$ & 250 & 300 & 350 \\
\hline $\mathrm{Cu}$ & 50 & 100 & 100 \\
\hline $\mathrm{Zn}$ & 200 & 250 & 300 \\
\hline
\end{tabular}


Table 2. Soil environmental quality grade.

\begin{tabular}{|c|c|c|c|}
\hline Grade & $\begin{array}{c}\text { Comprehensive } \\
\text { pollution index }\end{array}$ & Class of pollution & Pollution level \\
\hline 1 & $\mathrm{PC} \leq 0.7$ & Security & Clean \\
\hline 2 & $0.7<\mathrm{PC} \leq 1.0$ & Cordon & Relatively clean \\
\hline 3 & $1.0<\mathrm{PC} \leq 2.0$ & Mild pollution & $\begin{array}{c}\text { Soil pollutants exceed environmental quality standards, and crops are not } \\
\text { contaminated. }\end{array}$ \\
\hline 4 & $2.0<\mathrm{PC} \leq 3.0$ & Moderate pollution & Soil pollutants exceed environmental quality standards, and crops are polluted. \\
\hline 5 & $\mathrm{PC}>3.0$ & Severe pollution & Soil and crop pollution is quite serious \\
\hline
\end{tabular}

\section{Sample Analyses}

The heavy metals in the soil are digested with $\mathrm{HNO}_{3}$ - $\mathrm{HF}$ by microwave, and the heavy metals in plants are digested with $\mathrm{HNO}_{3}-\mathrm{H}_{2} \mathrm{O}_{2}$ by microwave and determined with ICP-OES (prodigy $\mathrm{xp}$ ). The reagents used for the determination of heavy metals are all of high purity. The containers are soaked in $\mathrm{HNO}_{3}(25-30 \%$ of content) for more than 8 hours and rinsed repeatedly with de-ionized water. The recovery rate of heavy metals in samples is between $83.17 \%$ and $112.74 \%$.

\section{Assessment Standards}

The limit values for heavy metals in soil are referred to in the national standard in Soil Environment Standards [15] (GB15618-1995) (See Table 1).

According to the National Technical Regulations for the Assessment of Soil Pollution Status (Trial), this paper combined the single pollution index method with a comprehensive assessment method and used the N.L. Nemerow comprehensive index method for assessment. The specific calculation method is as follows:

According to the single factor index method, $P_{i}=\frac{C_{\mathrm{i}}}{S_{i}}$

In the formula: $\mathrm{P}_{\mathrm{i}}$ is the single pollution index of the pollutant $i$ in the environment; $C_{i}$ is the real-time measured data of the pollutant $i$ in the environment; and $\mathrm{S}_{\mathrm{i}}$ is the assessment standard used for the pollutant i. If $\mathrm{P}_{\mathrm{i}}>1$, the soil is thus assessed as polluted.
According to the comprehensive pollution index method:

$$
P_{\text {综 }}=\sqrt{\frac{\left(\left(\frac{C_{\mathrm{i}}}{S_{\mathrm{i}}}\right) \max \right)^{2}+\left(\left(\frac{C_{\mathrm{i}}}{S_{i}}\right) \text { ave }\right)^{2}}{2}}
$$

In this formula, $\mathrm{P}$ is the comprehensive pollution index, $\left(\left(\frac{C_{\mathrm{i}}}{S_{\mathrm{i}}}\right) \max \right)^{2}$ is the square of the maximum value of the single pollution factor among all the pollutants in the soil, and $\left(\left(\frac{C_{\mathrm{i}}}{S_{i}}\right) \text { ave }\right)^{2} \quad$ is the square of the average value of all the single pollution factors of all the pollutants in the soil.

Based on the comprehensive pollution index, four kinds of heavy metal elements on the surface of the plough layer are assessed, and the heavy metal pollution in the soil is graded at the same time [16] (see Table 2).

The enrichment factor $(E F)$ characterizes the complexity of migration of heavy metals in the soilplant system, and also indicates the plant's ability to accumulate heavy metals. The higher the factor, the stronger the ability [17]. The formula is as follows:

$E F=\frac{\sum \text { Concentrations of heavy metal in each organ of the plant }}{\text { Concentrations of heavy metal in the soil }}$

Table 3. Total variation of heavy metals in soil of rice rape rotation.

\begin{tabular}{|c|c|c|c|c|c|c|c|c|c|c|}
\hline & \multicolumn{4}{|c|}{ Rape growth period } & \multicolumn{4}{c|}{ Rice growth period } \\
\hline Element & $\begin{array}{c}\text { Before } \\
\text { sowing }\end{array}$ & $\begin{array}{c}\text { Seedling } \\
\text { stage }\end{array}$ & $\begin{array}{c}\text { Bolting } \\
\text { stage }\end{array}$ & $\begin{array}{c}\text { Flores- } \\
\text { cence }\end{array}$ & $\begin{array}{c}\text { Harvest } \\
\text { period }\end{array}$ & $\begin{array}{c}\text { Before } \\
\text { sowing }\end{array}$ & $\begin{array}{c}\text { Seedling } \\
\text { stage }\end{array}$ & $\begin{array}{c}\text { Tillering } \\
\text { stage }\end{array}$ & $\begin{array}{c}\text { Filling } \\
\text { period }\end{array}$ & $\begin{array}{c}\text { Harvest } \\
\text { period }\end{array}$ \\
\hline $\mathrm{Cr}$ & 71.18 & 72.73 & 80.65 & 74.12 & 84.36 & 79.92 & 78.37 & 77.64 & 52.51 & 48.12 \\
\hline $\mathrm{Cd}$ & 1.41 & 1.67 & 1.73 & 1.72 & 1.55 & 1.35 & 1.81 & 1.73 & 0.57 & 0.48 \\
\hline $\mathrm{Pb}$ & 44.54 & 42.93 & 40.04 & 35.22 & 40.67 & 51.60 & 48.74 & 49.62 & 50.04 & 57.30 \\
\hline $\mathrm{Cu}$ & 19.54 & 18.11 & 17.99 & 16.94 & 19.75 & 28.76 & 29.75 & 30.14 & 12.29 & 13.81 \\
\hline
\end{tabular}




\section{Results and Analysis}

\section{Variation of Total Heavy Metal in Rice-Rape Rotation Soil}

Table 3 indicates that before the tillering stage of rice, the total amount of $\mathrm{Cr}$ in the soil is in a fluctuation state, but the fluctuation range is relatively narrow. The Cr fluctuation range is between 71.18-84.36 mg. $\mathrm{kg}^{-1}$, with a variation factor of $4.65 \%$. During the grain filling stage and harvesting stage, the total amount of $\mathrm{Cr}$ decreases consistently. Compared with that at the tillering stage, the amount of $\mathrm{Cr}$ at the filling stage decreases by $25.13 \mathrm{mg} \cdot \mathrm{kg}^{-1}$. The total amount of $\mathrm{Cr}$ in the soil is reduced during the bolting period and then increases during the following fluctuations. The gap of $\mathrm{Cr}$ content in the filling stage and harvesting stage of rice narrows once again. During the growth of rape, the amount of heavy metal $\mathrm{Cd}$ in soil first increases and then decreases, and peaks at the bolting stage. During the growth of rice, it increases first and then decreases in a similar pattern and peaks at the seedling stage at $1.81 \mathrm{mg} \cdot \mathrm{kg}^{-1}$. The variation of $\mathrm{Cd}$ content in the growth period of rice (with the variation factor of $47.56 \%$ ) is obviously greater than that in the growth process of rape (with the variation factor of $7.47 \%$ ).

During the rice-rape rotation process, the $\mathrm{Pb}$ content in the soil shows a pattern of growth in fluctuation. In the growth of rape, the content of $\mathrm{Cu}$ in the soil increases first and then decreases, with a variation factor of $5.67 \%$. In the growth process of rice, the content of $\mathrm{Cu}$ in the soil also increases first and then decreases, with a significantly greater variation factor than that of rape. Generally speaking, during the rice-rape rotation process, the trend of variation of the content of $\mathrm{Cu}$ in the soil is consistent.

\section{Assessing Heavy Metal Pollution in Soil with Rice-Rapeseed Rotation}

In reference to the soil environmental quality standards promulgated in China in 1995, the NL Nemerow comprehensive index method is used to calculate the single pollution index $\left(\mathrm{P}_{\mathrm{i}}\right)$ of heavy metals in the soil at various growth stages of rape and rice, as well as the comprehensive pollution index $\left(\mathrm{P}_{\mathrm{c}}\right)$ of the total amount of heavy metals in the soil in the growth processes of rape and rice, thus analyzing and assessing the heavy metal contents in the soil.

Table 4 indicates that the soil is moderately polluted with the heavy metal $\mathrm{Cd}$, while the contents of other metals are at safe levels. This conclusion correlates with the result of previous research, the conclusion of which was that there is no $\mathrm{Cr}$ pollution in Guizhou Province, the whole province is polluted by $\mathrm{Cd}$, and some local areas are polluted by $\mathrm{Pb}$. The pollution of the metal $\mathrm{Cd}$ is the most serious at the seedling stage of rice, while the content of the other four metals in the soil are at safe levels. The changing trends of the single factor

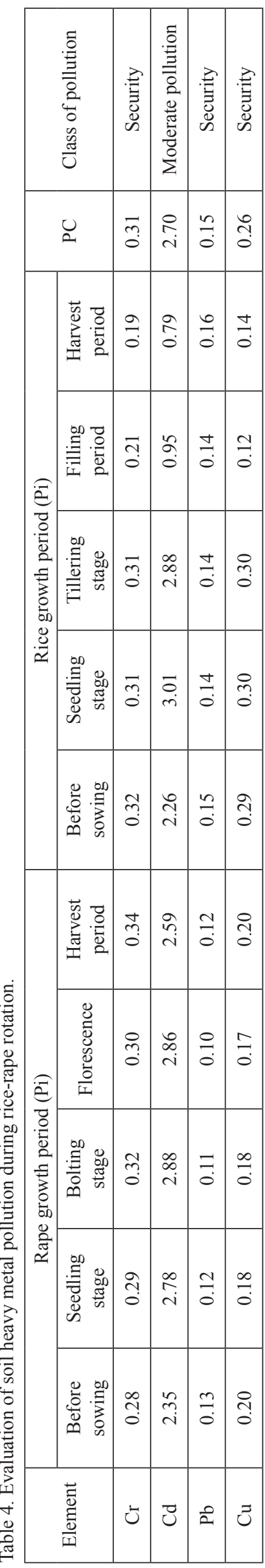


pollution indexes of the heavy metals in the whole growth period of rape and rice are distinguished. But regarding the comprehensive pollution index, the soil is more seriously contaminated with $\mathrm{Cr}$ and $\mathrm{Cd}$.

\section{Distribution of Heavy Metals in Different Organs at Different Growth Stages}

\section{Distribution of Heavy Metals in Different Organs of Rape at Different Growth Stages}

The content of $\mathrm{Cr}$ in various organs of rape at different growth stages are shown in Fig. 1a). Except for the lower content $\left(0.60 \mathrm{mg} \cdot \mathrm{kg}^{-1}\right)$ in the roots during the flowering stage, the $\mathrm{Cr}$ contents in the roots at the other three growth stages are higher than those in other organs, which is 11.48 times that in the stems and 9.55 times that in the leaves. From the seedling stage to the bolting stage, the content of $\mathrm{Cr}$ in rape stems and leaves see no remarkable changes, but the content of $\mathrm{Cr}$ in roots doubles. The content of $\mathrm{Cr}$ in stems and flowers are higher than those in the roots and leaves during the flowering stage; the difference of content of $\mathrm{Cr}$ in stems, seeds and pods during the harvesting stage is not notable and they are all lower than that in the roots. Rape mainly enriches the heavy metal $\mathrm{Cr}$ in the roots, and the content of $\mathrm{Cr}$ in stems is the lowest in each period.

Fig. 1b) showcases that the content of $\mathrm{Cd}$ (0.90 mg. $\mathrm{kg}^{-1}$ at the seedling stage, $0.80 \mathrm{mg} \cdot \mathrm{kg}^{-1}$ at the bolting stage, and $1.07 \mathrm{mg} \cdot \mathrm{kg}^{-1}$ at the flowering stage) of rape at the seedling stage, the bolting stage and the flowering stage are higher than those in other organs. During the harvesting stage, $\mathrm{Cd}$ is mainly enriched in pods and stems $\left(0.42 \mathrm{mg} \cdot \mathrm{kg}^{-1}\right.$ in pods and $0.39 \mathrm{mg} \cdot \mathrm{kg}^{-1}$ in stems). The content of $\mathrm{Cd}$ in roots and stems does not change much at different stages of growth. The content of $\mathrm{Cd}$ in roots at the seedling stage and the bolting stage are higher than those in stems. This is the opposite at the flowering and harvesting stages. Compared with other organs, the content of $\mathrm{Cd}$ in rape and seed are relatively low, indicating that they are not the main organs for enriching Cd. This is a result of the self-detoxification defense function of the plant. In the upward transit process of $\mathrm{Cd}$ in the soil, through the barrier function of roots, stems and pods, the amount of $\mathrm{Cd}$ entering the seed is greatly reduced, and the leaves in the flowering stage, with high transit factor, also intercept $\mathrm{Cd}$ before it enters the flower.

As can be seen from Fig. 1c), the content of $\mathrm{Pb}$ in the roots at the seedling stage and the bolting stage of rape (2.33 mg.kg ${ }^{-1}$ at the seedling stage and $3.90 \mathrm{mg} \cdot \mathrm{kg}^{-1}$ at the bolting stage) are higher than those in stems and leaves. The content of $\mathrm{Pb}$ in the stems and leaves are reduced during the bolting stage, while that in the roots is found to increase significantly (by $67.60 \%$ ). The distribution of $\mathrm{Pb}$ is relatively even in all organs during the flowering period, and the content of $\mathrm{Pb}$ in flowers $\left(2.03 \mathrm{mg} \cdot \mathrm{kg}^{-1}\right)$ is slightly higher. $\mathrm{Pb}$ is mainly concentrated in rape seeds and roots during the harvesting stage $\left(3.86 \mathrm{mg} \cdot \mathrm{kg}^{-1}\right.$ in seeds, and $2.35 \mathrm{mg} \cdot \mathrm{kg}^{-1}$ in roots). Therefore, although the heavy element $\mathrm{Pb}$ gradually migrates from roots to flowers and seeds during the growth of rape, at the same time the roots are the main organs that enrich $\mathrm{Pb}$. The content of $\mathrm{Pb}$ in rape is highest in roots, lowest
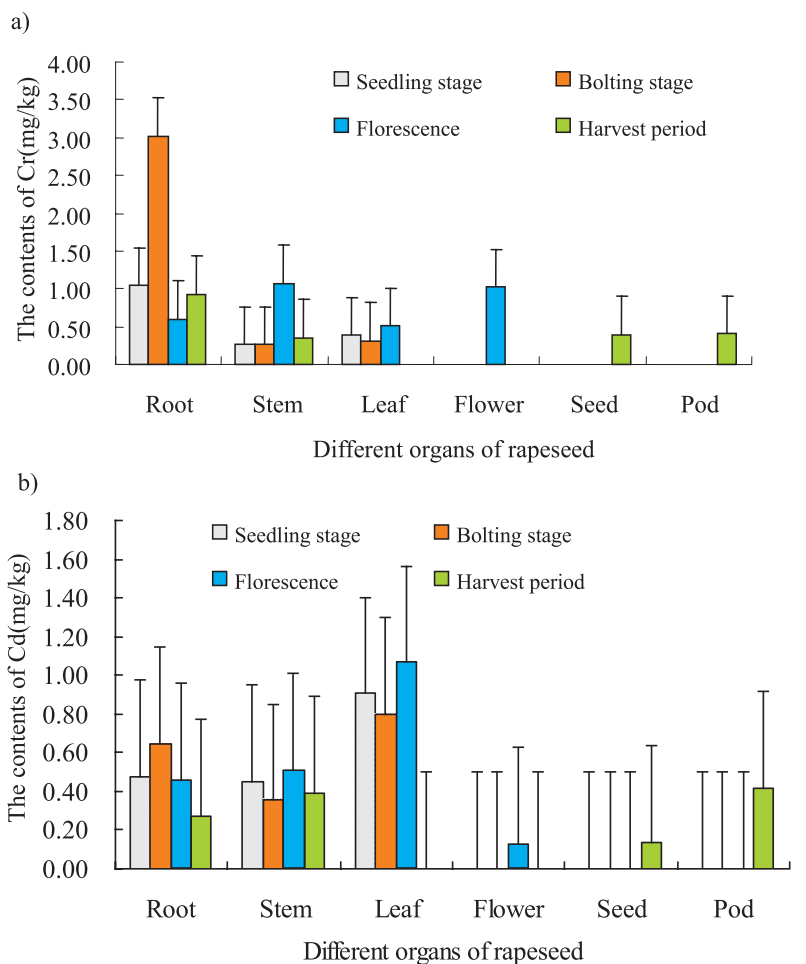

c)

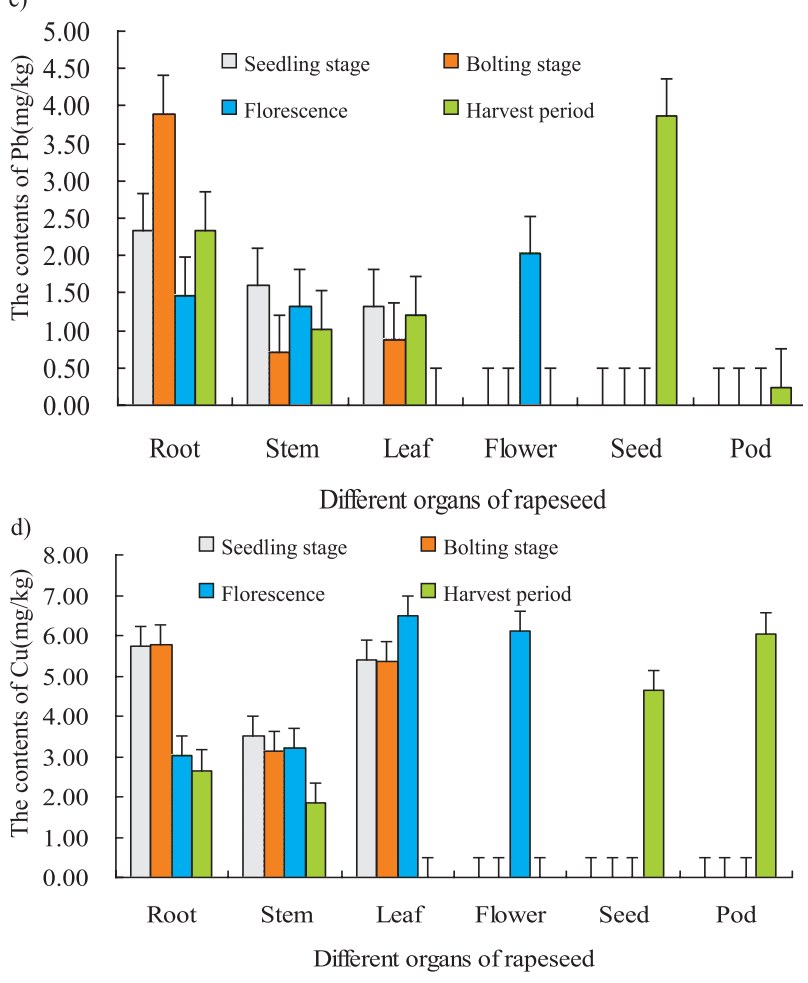

Fig. 1. Distribution of heavy metals in different organs of rape at different growth stages: a) concentrations of $\mathrm{Cr}, \mathrm{b}$ ) $\mathrm{Cd}$ ), c) $\mathrm{Pb}$, and d) $\mathrm{Cu}$. 
in leaves, and in-between in stems. Since the leaves fall during the harvesting period, the $\mathrm{Pb}$ content in the leaves is not involved in the comparison. The $\mathrm{Pb}$ content in the stems during the bolting stage is the lowest.

Fig. 1d) indicates that $\mathrm{Cu}$ is mainly enriched in roots and leaves at the seedling and bolting stages (5.72 mg. $\mathrm{kg}^{-1}$ in roots and $5.40 \mathrm{mg} \cdot \mathrm{kg}^{-1}$ in leaves at seedling stage, and $5.77 \mathrm{mg} \cdot \mathrm{kg}^{-1}$ and $5.36 \mathrm{mg} \cdot \mathrm{kg}^{-1}$ at bolting stage, respectively). During the flowering stage, it is mainly enriched in leaves and flowers (6.50 mg. $\mathrm{kg}^{-1}$ in leaves, $6.12 \mathrm{mg} \cdot \mathrm{kg}^{-1}$ in flowers), while at the harvesting stage it is mainly concentrated in seeds and pods (4.64 mg. $\mathrm{kg}^{-1}$ in seeds, $6.05 \mathrm{mg} \cdot \mathrm{kg}^{-1}$ in pods). From the seedling stage to the bolting period, the alternation of content of $\mathrm{Cu}$ in the organs is extremely minor, and the content in the roots during the flowering stage decreases sharply (by $47.80 \%$ ). During this period, the content of $\mathrm{Cu}$ in the flowers as a new organ is only lower than that in the leaves. The contents in the roots and stems at the harvesting stage continue to decline, and the seeds and pods replace the leaves and flowers as organs that mainly enrich $\mathrm{Cu}$. In general, the ability for enriching $\mathrm{Cu}$ of each organ of rape is relatively strong. $\mathrm{Cu}$ accumulates in the leaves along with the growth of rape.

\section{Distribution of Heavy Metals in Different Organs of Rice at Different Growth Stages}

The distribution of heavy metal $\mathrm{Cr}$ in various organs of rice at each growth stage is shown in Fig. 2a). Rice roots are the main organs for enriching $\mathrm{Cr}$ in the soil. Although the content of $\mathrm{Cr}$ in roots during growth stages varies, it is far higher than that in other organs. The content of $\mathrm{Cr}$ in rice stems gradually decreases and peaks at the seedling stage $\left(1.02 \mathrm{mg} \cdot \mathrm{kg}^{-1}\right)$. The content of $\mathrm{Cr}$ in rice leaves is relatively stable, and the $\mathrm{Cr}$ content in the grain at the harvesting stage $\left(0.51 \mathrm{mg} \cdot \mathrm{kg}^{-1}\right)$ is higher than that in the filling stage (0.31 mg.kg-1 $)$.

The distribution of heavy metal $\mathrm{Cd}$ in various organs during the growth period of rice is shown in Fig. 2b). Rice roots are the main organs for accumulating heavy metal $\mathrm{Cd}$. With the growth of rice, $\mathrm{Cd}$ content in roots gradually increases. The content of $\mathrm{Cd}$ in leaves is higher than that in stems, and both are relatively stable in the growth period of rice. The content of $\mathrm{Cd}$ in leaves varies, ranging from 0.19 to $0.21 \mathrm{mg} \cdot \mathrm{kg}^{-1}$, and the range of content variation in stems is between 0.06 and $0.09 \mathrm{mg} \cdot \mathrm{kg}^{-1}$. Although $\mathrm{Cd}$ content in the grain during the harvesting stage is higher than that in the filling stage, the content of $\mathrm{Cd}$ in non-glutinous rice is relatively low $\left(0.09 \mathrm{mg} \cdot \mathrm{kg}^{-1}\right)$.

The distribution of heavy metal $\mathrm{Pb}$ in various organs of rice at each growth stage is shown in Fig. 2c). Rice roots are the main organs for $\mathrm{Pb}$ enrichment, followed by stems. The $\mathrm{Pb}$ content in rice stems decreases with the growth of rice in general. The trend of variation is the opposite in the leaves.
The accumulated $\mathrm{Pb}$ in grains is mainly distributed in non-glutinous rice.

The distribution of heavy metal $\mathrm{Cu}$ in various organs of rice at different growth stages is shown in Fig. 2d). Rice roots are the main organs that enrich $\mathrm{Cu}$, followed by the leaves. $\mathrm{Cu}$ contents in the roots and leaves decrease during the entire growth period of rice. At the harvesting stage, $\mathrm{Cu}$ accumulation in rice grains is slightly higher than that in the leaves, and the rice stem is the organ with the lowest $\mathrm{Cu}$ content.
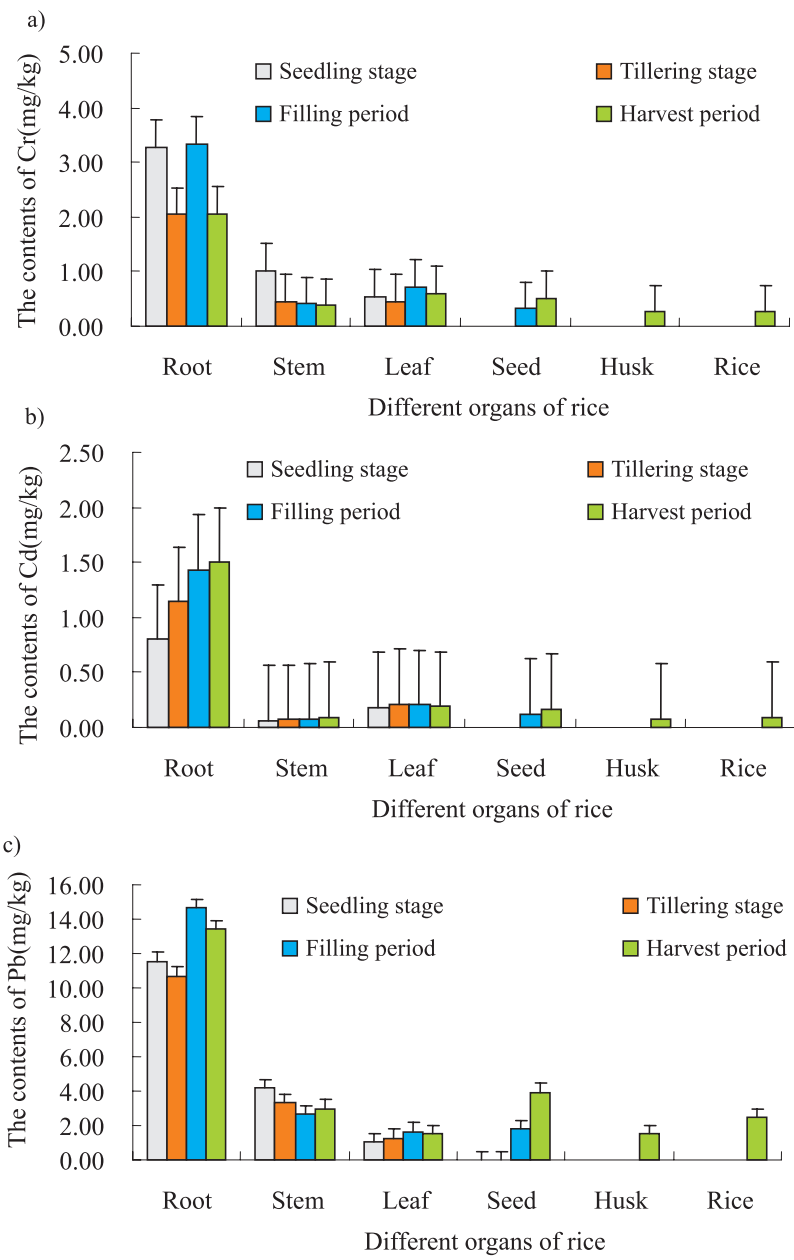

d)

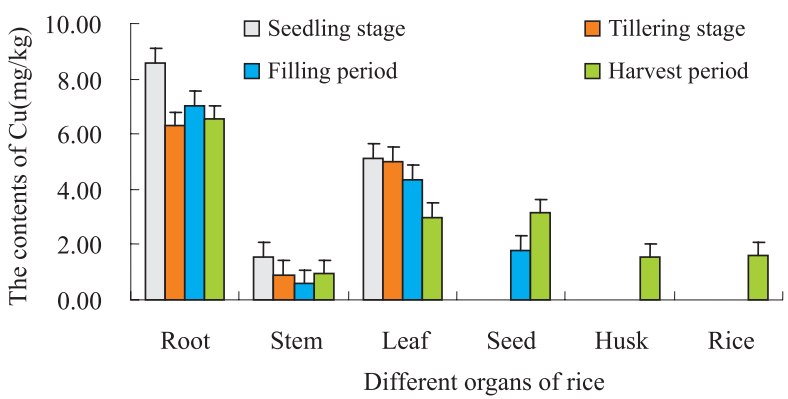

Fig. 2. Distribution of heavy metals in different organs of rice at different growth stages: a) concentrations of $\mathrm{Cr}, \mathrm{b}) \mathrm{Cd}$ ), c) $\mathrm{Pb}$, and d) $\mathrm{Cu}$. 
Table 5. Enrichment of heavy metals in soils during the growth of rape and rice.

\begin{tabular}{|c|c|c|c|c|c|c|c|c|c|c|}
\hline \multirow{2}{*}{ Element } & \multicolumn{4}{|c|}{ Rape growth period (Pi) } & \multicolumn{5}{c|}{ Rice growth period (Pi) } \\
\cline { 2 - 14 } & Before sowing & $\begin{array}{c}\text { Seedling } \\
\text { stage }\end{array}$ & $\begin{array}{c}\text { Bolting } \\
\text { stage }\end{array}$ & Florescence & $\begin{array}{c}\text { Harvest } \\
\text { period }\end{array}$ & $\begin{array}{c}\text { Before } \\
\text { sowing }\end{array}$ & $\begin{array}{c}\text { Seedling } \\
\text { stage }\end{array}$ & $\begin{array}{c}\text { Tillering } \\
\text { stage }\end{array}$ & $\begin{array}{c}\text { Filling } \\
\text { period }\end{array}$ & $\begin{array}{c}\text { Harvest } \\
\text { period }\end{array}$ \\
\hline $\mathrm{Cr}$ & 0.02 & 0.04 & 0.04 & 0.02 & 0.06 & 0.04 & 0.09 & 0.07 & 0.02 & 0.04 \\
\hline $\mathrm{Cd}$ & 1.10 & 1.04 & 1.26 & 0.78 & 0.58 & 0.82 & 3.21 & 4.10 & 1.10 & 1.04 \\
\hline $\mathrm{Pb}$ & 0.12 & 0.14 & 0.17 & 0.18 & 0.34 & 0.31 & 0.41 & 0.38 & 0.12 & 0.14 \\
\hline $\mathrm{Cu}$ & 0.81 & 0.79 & 1.11 & 0.77 & 0.51 & 0.41 & 1.12 & 0.99 & 0.81 & 0.79 \\
\hline
\end{tabular}

\section{Accumulation of Heavy Metals in Rape and Rice}

The content of heavy metals in crops is closely related to the ability of the crops to concentrate these heavy metals. Meanwhile, the ability of a crop to concentrate different heavy metals varies (Table 5). The enrichment factor (EF) reflects the plant's ability to concentrate heavy metals in the soil. Regarding the $\mathrm{EF}$ in the growth process of rape for heavy metals, it comes first for $\mathrm{Cd}$ (between 0.78 1.26), and last for $\mathrm{Cr}$ (between 0.02 and 0.04). The ability of rape for the accumulation of the same heavy metal at different growth stages also differs. The abilities of enriching $\mathrm{Cd}$ and $\mathrm{Cu}$ of rape during its growth process are basically the same. The EF decreases first, then increases, and decreases again. The enrichment abilities of these two heavy metals are the strongest at the flowering stage and the weakest during the harvesting stage. The flowering period witnesses the most vigorous period of rape growth, with rigorous metabolism of various organs. The tolerance of heavy metals and the metabolic mechanism are therefore enhanced, and the total amount of heavy metals that the roots absorb from the soil increase, while the ability to transit the heavy metals to other organs is also enhanced. In the harvesting period, with the aging of the plant, the metabolic abilities of various organs weaken, and the abilities to enrich heavy metals also weaken. The leaves, roots and stems of the rape are the main organs for $\mathrm{Cd}$ accumulation at all stages of growth.

On the whole, the EFs of $\mathrm{Pb}$ and $\mathrm{Cu}$ during the growth of rice are basically the same, exhibiting a tendency to weaken at first, strengthen next, and weaken again. There is no significant characteristic of enrichment for $\mathrm{Cr}$ and $\mathrm{Pb}$, with both $\mathrm{EFs}$ less than 1 ; the enrichment ability of $\mathrm{Cd}$ is gradually enhanced, at 3.21 and 4.10 at the filling and harvesting stages, respectively. Studies have shown that EF can be used to measure the hyper-enrichment feature of plants for heavy metals, that is, EF greater than 1 serves as one of the assessment criteria for determining plants with hyper-enrichment capabilities for heavy metals. This shows that the cumulative effect of $\mathrm{Cd}$ in this variety of rice is very strong, indicating that this variety may be a plant of hyper-enrichment of $\mathrm{Cd}$ and deserves further focus.

\section{Discussion}

With the increasing attention of the international community on the heavy metal pollution of soil, the enrichment and pollution of the heavy metals in cultivated lands are of wide concern in various sectors of society and researchers from different disciplines [18]. Heavy metal pollution of soil is a serious danger to the biological environment, food safety and people's health [19]. The enrichment of heavy metals in farmland not only leads to land degradation, but also quantity reduction and quality degradation of agricultural products [20]. Besides, due to the fact that the heavy metal is hard to be degraded but easy to be accumulated in the soil-plant system, it not only does harm to the growth and development of plants and animals, but also threatens the survival and health of human beings [21].

The content of heavy metals in crops is closely related to the enrichment ability of crops for heavy metals. Meanwhile, one kind of crop has different enrichment abilities for different kinds of heavy metals [22]. The enrichment factor indicates the enrichment ability of plants for heavy metals in soil. In the different growth stages of rape, leaf, root and stem are the main enrichment organs, which is basically consistent with the research results of predecessors [23]. The enrichment ability of rape for $\mathrm{Cu}$ is weaker than that for $\mathrm{Cd}$, which is the same as the results in Zhang Min's study on the influences on the growth of rape under $\mathrm{Cu}$ and $\mathrm{Cd}$ stress [24]. Except for stems, other organs all have quite strong enrichment ability for $\mathrm{Cu}$. Although there are both $\mathrm{Pb}$ and $\mathrm{Cd}$, rape's enrichment ability for $\mathrm{Pb}$ is much weaker than that for $\mathrm{Cd}$, which is because $\mathrm{Pb}$ will capture the adsorption sites of $\mathrm{Cd}$ in soil, and then $\mathrm{Pb}$ is easier to be changed into sediment through chemical reactions, fixed in soil and therefore is hard to be absorbed by rape's root system [25].

Heavy metals in soil are accumulated into plants through the root system and transported into different organs [26]. Different plants have different enrichment and transport abilities for the same kind of heavy metal, and one kind of plant has different enrichment and transportation abilities for different heavy metals [27]. Hyperaccumulation plants are often used for soil remediation in the face of heavy metal pollution of soil. Taking the remediation period, effects of 
accumulation, economic value and environmentally friendly process into overall consideration, many crops are used to restore the heavy metal pollution of farmland [28]. Roots contact soil directly and are the main organ for accumulating heavy metals, which can be seen obviously in terms of the accumulation of $\mathrm{Cr}$, $\mathrm{Cd}$ and $\mathrm{Pb}$. As for $\mathrm{Cu}$, besides roots, leaves and grains are also important organs for enrichment [29]. Previous research has mostly focused on the comparison among the content of heavy metals in different organs in the harvest period, which generally come to the conclusion that the sequence of the content is root system $>$ stem $>$ leaf $>$ grain. There are also studies that show that the sequence should be root system $>$ stem $>$ grain $>$ leaf. In this study, different elements have different sequences. For example, the sequence of $\mathrm{Cr}$ and $\mathrm{Cd}$ is root system $>$ leaf $>$ grain $>$ stem, $\mathrm{Pb}$ root system $>$ grain $>$ stem $>$ leaf and $\mathrm{Cu}$ root system $>$ grain $>$ leaf $>$ stem.

\section{Conclusions}

This study focused on the accumulation of soil heavy metals in rice and rape. The conclusions are as follows. In rice-rape rotation, the changing trends of the $\mathrm{Cr}$ content and $\mathrm{Cd}$ content, which are all heavy metals in soil, were similar to each other. In the growth period of rape and before the tillering stage of rice, the $\mathrm{Cr}$ content and $\mathrm{Cd}$ content showed a trend of fluctuations. After the tillering stage of rice, the $\mathrm{Cr}$ content and $\mathrm{Cd}$ content decreased significantly while the content of soil heavy metal $\mathrm{Pb}$ increased in fluctuations as a whole. The content of soil heavy metal $\mathrm{Cu}$ was relatively stable in the growth of rape, while for rice the $\mathrm{Cu}$ content increased first and then decreased. The changing scope of the latter was obviously larger than that of the former. This paper also evaluated the heavy metal pollution of soil through single pollution indexes and comprehensive pollution index. The soil heavy metal $\mathrm{Cr}, \mathrm{Pb}$ and $\mathrm{Cu}$ were all at a level of "clean" and the soil heavy metal $\mathrm{Cd}$ was at a middle level of pollution. As for rice, the $\mathrm{Cd}$ pollution was the most serious in its seeding stage. The sequence of rape's enrichment ability for heavy metals was $\mathrm{Zn}>\mathrm{Cd}>\mathrm{Cr}$. In different growth stages of rape, leaf, root and stem were the main enrichment organs for $\mathrm{Cd}$. Rice's enrichment ability for heavy metals was relatively weaker in the seeding stage and tillering stage, while its enrichment ability for $\mathrm{Cd}$ was gradually strengthened and reached its peak in the harvest period. In all growth stages, rice mainly accumulated heavy metals in the root system and only a little was transported into other organs.

\section{Acknowledgements}

This work was supported by the National Natural Science Foundation of China (No. 41561075); the Guizhou science and technology support plan project
(No. [2019] 2840, [2017] 1176, [2017] 2860, [2018] 2349, [2016] 2595-2); the Guizhou outstanding youth science and technology talent project (No.[2017]5622); the Team Construction of Science and Technology Innovation (No. QKH-RCTD (2015) 4012), the Doctor Foundation of Guizhou Medical University (YJ2017-16) and firstclass discipline construction projects in Guizhou Province (No. QJKY (2017)85).

\section{References}

1. ZHANG J.Y., DAI M.H., WANG L.C., ZENG C.F., SU W.C. The challenge and future of rocky desertification control in karst areas in southwest China. Solid Earth Discussions. 7, 3271, 2015.

2. LI Q., HU Q.J., ZANG C.L., JING Z.J. Effects of Pb, Cd, $\mathrm{Zn}$, and $\mathrm{Cu}$ on Soil Enzyme Activity and Soil Properties Related to Agricultural Land-Use Practices in Karst Area Contaminated by Pb-Zn Tailings. Pol. J. Environ. Stud. 27 (6), 2623, 2018.

3. WANG D.J., SHEN Y.X., HUANG J. Epilithic organic matter and nutrient contents in three different karst. Mountain Research, 2015.

4. KUZYAKOV Y., BLAGODATSKAYA E. Microbial hotspots and hot moments in soil: Concept \& review. Soil Biol. Biochem. 83, 184, 2015.

5. YING B., XIAO S.Z. XIONG K.N., CHENG Q.W., LUO J.S. Comparative studies of the distribution characteristics of rocky desertification and land use/land cover classes in typical areas of Guizhou province, China. Environmental Earth Sciences.71, 631, 2012.

6. LI Z., JIN Z., LI Q. Changes in land use and their effects on soil properties in Huixian karst wetland system. Pol. J.Environ. Stud. 26 (3), 699, 2017.

7. JIANG Z., LIAN Y., QIN X. Rocky desertification in Southwest China: Impacts, causes, and restoration. EarthScience Reviews. 132, 1, 2014.

8. LIU C.Q. Biogeochemical processes and cycling of nutrients in the earth's surface: Cycling of nutrients in soil-plant plant systems of karstic environment, Southwest China. Beijing: Science Press. 80, 2009.

9. WANG D.J., SHEN Y.X, HUANG J., LI Y.H. Rock outcrops redistribute water to nearby soil patches in karst landscapes. Environ Sci Pollut Res. 23, 8610, 2016.

10. CHEN S.Z., ZHOU Z.F., YAN L.H., LI B. Quantitative Evaluation of Ecosystem Health in a Karst Area of South China. Sustainability. 8, 975, 2016.

11. LI C., XIONG K.N., WU G.M. Process of biodiversity research of karst areas in China. Acta Ecologica Sinica. 33,192, 2013.

12. YANG Y., LI H.L.,LING P. Assessment of $\mathrm{Pb}$ and $\mathrm{Cd}$ in seed oils and meals and methodology of their extration. Food Chemistry, 197, 482, 2016.

13. YEH T.Y., LIN C.L., LIN C.F., CHEN C.C. Chelatorenhanced phytoextraction of copper and zinc by sunflower, Chinese cabbage, cattails and reeds. Int J Sci Technol. 12, 327, 2015.

14. DUZGOREN-AYDIN N.S., WONG C.S.C., AYDIN A., SONG Z., YOU M., LI X.D. Heavy metal contamination and distribution in the urban environment of Guangzhou, SE China. Environmental Geochemistry and Health, 28 (4), 375, 2006. 
15. THE MINISTER OF HEALTH OF THE PEOPLE'S REPUBLIC OF CHINA. The Standardization Administration of the People's Republic of China. Maximum levels of contaminants in foods (GB156181995), 2005 [In Chinese].

16. HU Y., CHENG H. A method for apportionment of natural and anthropogenic contributions to heavy metal loadings in the surface soils across large-scale regions. Environmental Pollution, 214, 400, 2016.

17. BRUNETTI G., FARRAG K., ROVIRA P.S., NIGRO F., SENESI N. Greenhouse and field studies on $\mathrm{Cr}, \mathrm{Cu}, \mathrm{Pb}$ and Zn phytoextraction by Brassica napus from contaminated soils in the Apulia region, Southern Italy. Geoderma, 160 (3), 519, 2011.

18. VAN -OORT F., THIRY M., FOY E., FUJISAKI K., DELARUE G., DAIRON R., JONGMANS T. Impacts of one century of wastewater discharge on soil transformation through ferrolysis and related metal pollutant distributions. Sci. Total Environ. 590, 1, 2017.

19. ZHU C., TIAN H., CHENG K., LIU K., WANG K., HUA S., GAO J., ZHOU J. Potentials of whole process control of heavy metals emissions from coal-fired power plants in China. Journal of Cleaner Production, 114, 350, 2015.

20. ĆUJIĆ M., DRAGOVIĆ S., ĐORĐEVIĆ M., DRAGOVIĆ R., GAJIĆ B. Environmental assessment of heavy metals around the largest coal fired power plant in Serbia. Catena, 139, 46, 2016.

21. XU X., MENG B., ZHANG C., FENG X., GU C., GUO J., BISHOP K., XU Z., ZHANG S., QIU G. The local impact of a coal-fired power plant on inorganic mercury and methyl-mercury distribution in rice (Oryza sativa L.). Environmental Pollution, 223, 13, 2017.

22. MAHAR A., WANG P., ALI A., AWASTHI M.K., LAHORI A.H., WANG Q., LI R.H., ZHANG Z.Q.
Challenges and opportunities in the phytoremediation of heavy metals contaminated soils: A review. Ecotox Environ Safe. 126, 111, 2016.

23. ZHANG Q., YE J., CHEN J., XU H., WANG C., ZHAO M. Risk assessment of polychlorinated biphenyls and heavy metals in soils of an abandoned e-waste site in China. Environmental Pollution, 185 (4), 262, 2014.

24. DASKALAKIS K.D., O'CONNOR T.P. Normalization and elemental sediment contamination in the coastal United States. Environmental Science \& Technology, 29 (2), 475, 1995.

25. JIN Z., LI Z., LI Q., HU Q., YANG R., TANG H., LI G. Canonical correspondence analysis of soil heavy metal pollution, microflora and enzyme activities in the $\mathrm{Pb}-\mathrm{Zn}$ mine tailings dam collapse area of Sidi Village, SW China. Environ. Earth Sci. 73 (1), 267, 2015.

26. MUGOŠA B., ĐUROVIĆ D., NEDOVIĆ-VUKOVIĆ M., BARJAKTAROVIĆ-LABOVIĆ S., VRVIĆ M. Assessment of ecological risk of heavy metal contamination in coastal municipalities of montenegro. International Journal of Environmental Research \& Public Health, 13 (4), 393, 2016.

27. NATIONAL SOIL SURVEY OFFICE. Chinese soil genus records, Volumes 1-6. Beijing: China Agriculture Press, 1995 [In Chinese].

28. YANG L., JIANG L.F., WANG G.P., CHEN Y.H., SHEN Z.G., LUO C.L. Assessment of amendments for the immobilization of $\mathrm{Cu}$ in soils containing EDDS leachates. Environ Sci Pollut R. 22, 16525, 2015.

29. GUERR F., TREVIZAM A.R., MURAOKA T., MARCANTE N.C. Heavy metals in vegetables and potential risk for human health. Scientia Agricola, 69 (69), 54, 2012. 